\title{
Epidemiology of Mandibular Fractures Treated in a Brazilian Level I Trauma Public Hospital in the City of São Paulo, Brazil
}

\author{
Marcelo Zillo MARTINI \\ André TAKAHASHI \\ Humberto Gomes de OLIVEIRA NETO \\ José Pereira de CARVALHO JÚNIOR \\ Ricardo CURCIO \\ Elio Hitoshi SHINOHARA
}

Department of Oral and Maxillofacial Surgery of the Hospital Complex of Mandaqui (SUS/SP), São Paulo, SP, Brazil

\begin{abstract}
This article reviews cases of mandibular fractures treated at the Service of Oral and Maxillofacial Surgery of the Hospital Complex of Mandaqui (SUS/SP), which is a reference hospital complex for trauma in the northern area of the city of São Paulo, Brazil. Ninety-eight patients with mandibular fractures were seen at the hospital between January and December, 2001. Out of this total, 91 cases whose files were deemed adequate in terms of data accuracy and completeness were reviewed. The following data were collected for the study: age, gender, etiology, anatomical fracture site, treatment modality, relation to other facial bone fractures, hospitalization time and posttrauma complications. Motorcycle accident was the major cause of mandibular fractures followed by physical aggression and height fall. The mandibular anatomical sites of higher fracture incidence were: body, symphysis and condyle. The most commonly performed treatment modes were conservative approach or open reduction and intraosseous fixation. In conclusion, motorcycle accidents were associated with a larger number of facial fractures and most predominantly affect 21-30 year-old males. On the average, motor vehicle accident victims had more (and more severe) fractures than physical aggression victims. Complications were mostly associated with angle fractures and hospitalization period. Polytraumatized patients presented greater morbidity for complications.
\end{abstract}

Key Words: epidemiological studies, mandibular fractures, motorcycle accidents.

\section{INTRODUCTION}

North-American studies have pointed to either car accidents $(1,2)$ or physical assaults (3) as the major causes of mandibular fractures. A European study referred to aggressions as the main etiology for mandibular fractures (4) while other authors mentioned road accidents $(5,6)$.

A review of 450 cases of bone facial fractures in the city of São Paulo (Brazil) showed that the main cause of facial bone fractures were traffic accidents (7). Another survey found that out of 550 cases of facial fractures, most part (29.2\%) was in the mandible (8). However, the compulsory use of car seat belts and motorcycle helmets has changed this scenario. Klenk et al. (9) reported that the incidence of maxillofacial traumas due to car accidents decreased in developed countries after the compulsory use of seat belt. Brazilian studies have shown that mandibular fractures most often result from aggressions (10) or car accidents (11).

Data relative to mandibular fractures have changed in Brazil over time, especially as far as the region is concerned $(7,8,10,11)$. This article reviews cases of mandibular fractures treated at the Service of Oral and Maxillofacial Surgery of the Hospital Complex of Mandaqui (SUS/SP), which is a reference hospital complex for trauma in the northern area of the city of São Paulo, Brazil.

Correspondence: Dr. Marcelo Zillo Martini, Rua Aristarco Nogueira, 22, 13206-380 Jundiaí, SP, Brasil. Tel: +55-11-45265121. e-mail: martinifopunicamp@yahoo.com 


\section{PATIENTS AND METHODS}

In 2001, 98 patients with mandible fractures were treated at the Service of Oral and Maxillofacial Surgery of the Hospital Complex of Mandaqui (SUS/ $\mathrm{SP}$ ), which is a Brazilian public hospital and level I trauma center located in the city of São Paulo. Several polytraumatized patients are referred to this hospital.

Out of 98 patients, 91 cases whose files were deemed adequate in terms of data accuracy and completeness were reviewed. The following data were collected: age, gender, etiology, anatomical fracture site, treatment modality, relation with other facial bone fractures, hospitalization time and posttrauma complications. Killey (12) classification was used to rate the mandibular fractures, which were treated conservatively or by open reduction and intraosseous fixation.

\section{RESULTS}

Age Group and Gender. The patients' age ranged from 3 to 72 years (mean age 27. 3 years). Seventy-nine patients were men (87\%) and 12 were women (13\%), corresponding to a 6.6:1 male-to-female ratio. The highest incidence of mandibular fractures among male patients occurred between 21 and 30 years old; for women, mandibular fractures most often occurred between the ages of 11 and 20 (Fig. 1).

Etiology. Figure 2 shows the distribution of polytraumatized patients with mandibular fractures according to the etiology. Motorcycle accidents were the main cause of mandibular fractures (20 cases; 22\%); 17 were men (Figs. 3 and 4) and the most affected age range was 21-30 years (Fig. 5). Physical aggression was the second most common cause, occurring only in men (15 cases), mainly aged 31-40 years.

Anatomical Fracture Site. The most commonly affected anatomical site was the mandibular body (46 cases; 30.9\%) followed by symphysis (41 cases; $27.5 \%$ ), condylar process (24 cases; 16.1\%), angle (18 cases; $12.1 \%$ ), alveolar process (11 cases; $7.4 \%$ ), ramus (6 cases; 4\%) and coronoid process (3 cases; 2\%) (Fig. 6). Sixty-two patients (68.13\%) had at least one open fracture while the other 29 patients (31.87\%) did not have open fractures. Unilateral fractures occurred in 48 cases (53\%) and the other 43 patients (47\%) had bilateral fractures. Out of 91 patients, 44 (48.35\%) had a 1-part mandibular fracture, 37 (40.65\%) had a 2-part fracture, 9 (9.9\%) had a 3-part fracture and only 1 patient (1.1\%) had a 4-part mandibular fracture. Figure 7 shows the association between the anatomical fracture sites and the etiology of the trauma.

Relation with Other Facial Bone Fractures. Sixty-eight patients (75\%) had only mandibular fractures and the other 23 (25\%) had also other facial bone fractures. Fractures of the maxillary bones and zygomatic complex were the most frequently associated with mandibular fractures (7 cases each; 31\%). Figure 8 shows the facial fractures associated with mandible fractures. Motorcycle accidents responded for most mandibular fractures (10 cases; 43.47\%), followed by car accidents (4 cases; 17.39\%), and height falls (3 cases; 13.04\%). Bicycle accidents, gunshot wounds and running over occurred in 2 cases each (8.69\%).

Monthly Distribution of the Mandibular Fractures. Review of mandibular fractures in males over 1 year showed that March had the highest incidence (12 cases; $13.18 \%$ ), followed by November (11 cases; $12.08 \%)$ and October (10 cases; 10.98\%). February and December had the least number of fractures (3 cases each; 3.29\%) (Figs. 3 and 4). Unlike men, no difference in mandibular trauma incidence was observed in females within the evaluated 12-month period.

Treatment Modality. Thirty-two patients (35.2\%) received conservative treatment, 19 (59.37\%) were treated with closed reduction and intermaxillary fixation, $4(12.5 \%)$ were treated with mandible cerclages or cerclage associated with acrylic splint, 8 (25\%) were only followed up and 1 patient (3.12\%) was treated with intermaxillary fixation associated with cerclage. Two patients died and 3 did not undergo any treatment. Fiftyfour patients (59.3\%) underwent surgical treatment. Figure 9 shows the various techniques for fixation used in the different anatomical sites. The rigid fixation with the use of plates was the most predominant technique (34.2\%) in 97 fractures (65.1\% of the total of 149 fractures) that were treated with open reduction.

Posttrauma Complications. Out of 91 patients, 18 (19.7\%) had complications. From these, 12 had infection (66\%). The second most predominant complication was malocclusion ( 2 cases; $10 \%$ ). Trismus, lack of union, mobility and salivary fistula had 1 case each. Surgically treated patients with postoperative complications had a mean hospitalization time of 10.35 days. Those without complication had a mean hospitalization time of 5.4 days. The mean hospitalization time of 
patients with infection was 9.75 days, regardless of received or not an invasive treatment. In 10 cases of infection (83.3\%), the patient had two or more mandibular fractures and in 2 cases there was a fracture line

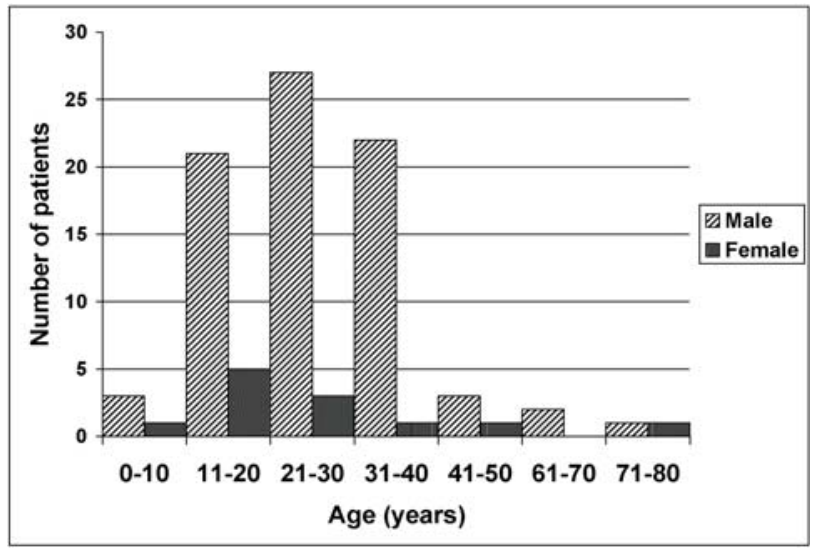

Figure 1 . Gender and age distribution of the 91 patients with mandibular fractures evaluated in this study.

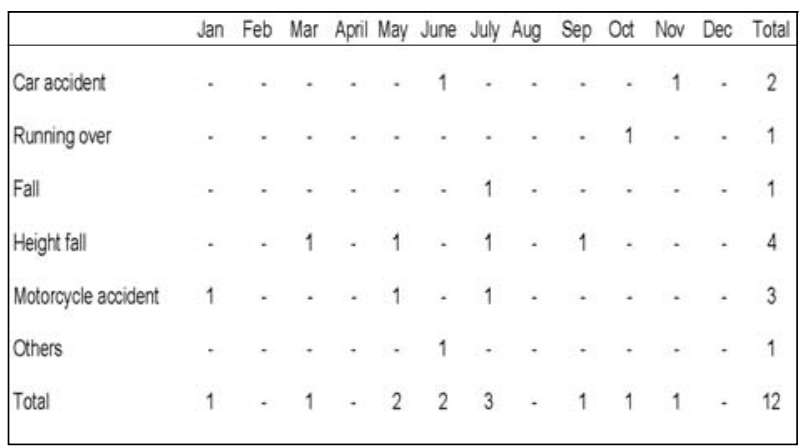

Figure 3. Monthly distribution of etiologies for women.

\begin{tabular}{|c|c|c|c|c|c|c|c|c|c|c|c|}
\hline Age & $\begin{array}{c}\text { Physical } \\
\text { Aggression }\end{array}$ & $\begin{array}{c}\text { Car } \\
\text { accident }\end{array}$ & $\begin{array}{l}\text { Running } \\
\text { over }\end{array}$ & Fall & Height tall & $\begin{array}{c}\text { Sport } \\
\text { accident }\end{array}$ & $\begin{array}{l}\text { Gunshot } \\
\text { wound }\end{array}$ & $\begin{array}{l}\text { Motorerycle } \\
\text { accident }\end{array}$ & $\begin{array}{l}\text { e Bicycle } \\
\text { accident }\end{array}$ & Other & Total \\
\hline 0.10 & 1 & $\cdot$ & $\cdot$ & $\cdot$ & 2 & $\cdot$ & $\cdot$ & $\cdot$ & 1 & $\cdot$ & $4(4.4 \%)$ \\
\hline $11 \cdot 20$ & 5 & 3 & 1 & . & 4 & 2 & 2 & 6 & 4 & . & $27(20.78)$ \\
\hline $21 \cdot 30$ & 1 & 3 & 3 & 2 & 2 & 1 & 1 & 11 & 2 & 4 & $30(33.0 \%)$ \\
\hline $31-40$ & 8 & 1 & 2 & 1 & 1 & . & 6 & 3 & . & . & $22(24.226)$ \\
\hline $41 \cdot 50$ & . & 1 & 2 & . & 1 & . & . & . & . & . & $4(4.46)$ \\
\hline 61.70 & . & . & . & 1 & 1 & . & . & . & . & . & $2(22 \%)$ \\
\hline $71-80$ & $\cdot$ & . & 2 & . & . & . & . & . & . & . & $2(22 \%)$ \\
\hline Total & $15(16.5) \%$ & $8(8.8 \%)$ & $10(119)$ & $4(4.4 \%)$ & $11(12.1 \%)$ & $3(3.3 \%)$ & $9(9.96)$ & $20(22 \%)$ & $7(7.7 \%)$ & $4(4.46)$ & ) $91(100 \%$ ) \\
\hline
\end{tabular}

Figure 5. Etiology distribution according to the patients's age range.
(16.7\%). From infected fractures, angle was the most commonly affected site (41.7\%) and the main etiologies related to complications were: aggression (7 cases; $58.3 \%$ ) and motorcycles accidents (2 cases; 18.6\%).

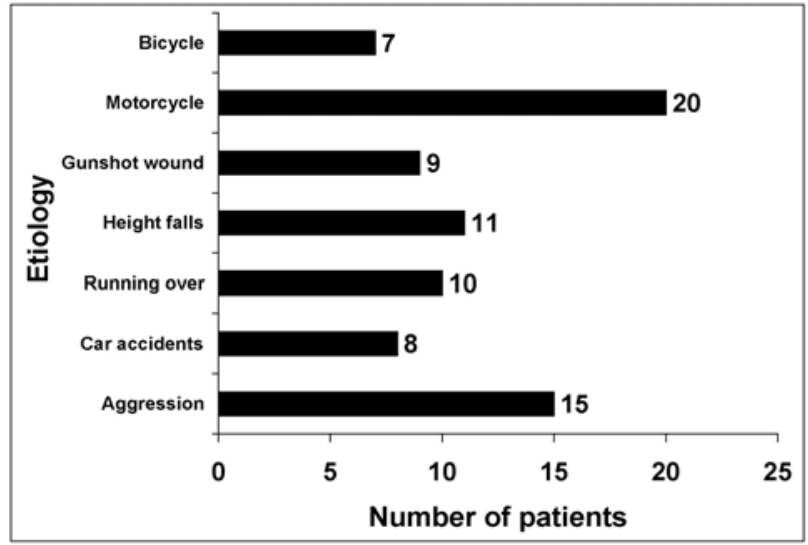

Figure 2. Distribution of the polytraumatized patients according to the etiologies.

\begin{tabular}{|c|c|c|c|c|c|c|c|c|c|c|c|c|c|}
\hline & Jan & Feb & Mar & April & May & June & July & Aug & Sep & Oct & Nov & Dec & Total \\
\hline Aggression & 1 & 1 & $\cdot$ & 3 & 1 & $\cdot$ & $\cdot$ & 2 & 2 & 1 & 2 & 2 & 15 \\
\hline Car accident & - & . & 1 & 1 & 1 & 1 & - & 1 & 1 & - & - & - & 6 \\
\hline Running over & 2 & 1 & - & 2 & - & - & - & . & . & 1 & 3 & - & 9 \\
\hline Fall & - & 1 & 2 & - & - & . & . & - & - & - & - & . & 3 \\
\hline Hoight fall & 2 & - & 2 & - & . & - & . & 2 & 1 & - & . & . & 7 \\
\hline Sport accident & - & - & 1 & - & - & - & - & - & - & 2 & - & - & 3 \\
\hline Gunshot wound & - & . & 2 & - & 1 & 1 & . & 1 & 1 & 1 & 2 & - & 9 \\
\hline Motorcycle accident & 2 & - & 2 & 2 & 3 & 1 & 1 & - & 1 & 2 & 3 & . & 17 \\
\hline Bicycle accident & - & . & 1 & 1 & - & . & . & 2 & 1 & 1 & - & 1 & 7 \\
\hline others & - & - & - & - & 1 & - & - & - & - & 1 & - & - & 2 \\
\hline Unknown & - & - & . & - & - & 1 & . & - & . & - & . & $\cdot$ & 1 \\
\hline Total & 7 & 3 & 11 & 9 & 7 & 4 & 1 & 8 & 7 & 9 & 10 & 3 & 79 \\
\hline
\end{tabular}

Figure 4. Monthly distribution of etiologies for men.

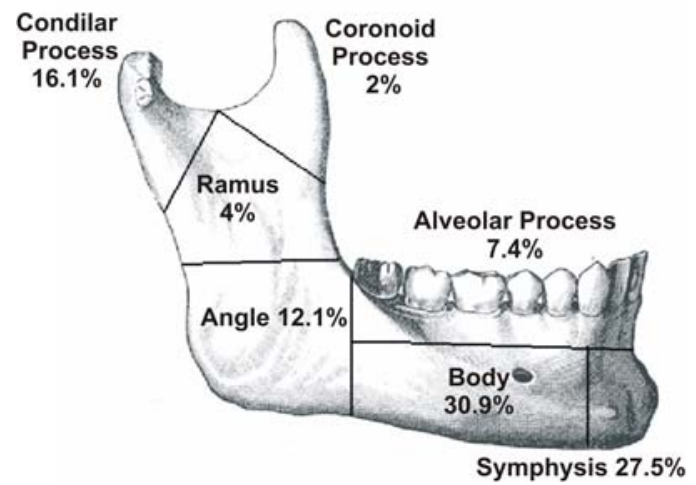

Figure 6. Distribution of the anatomical fracture sites (Modified from Gray, H.: Anatomy of the human body, 1918). 


\section{DISCUSSION}

Data from the Brazilian Institute of Geography and Statistics (13) relative to the latest demographic census (revision 2000) shows that the city of São Paulo has 10.434.252 habitants, of which 4.972 .678 (48\%) are men and 5.461.574 (52\%) are women (1:1.1). The age pyramid reveals a developing country with predominance of young people and life expectancy of 68.56 years. The Southeast of Brazil has a subtropical climate and the population has a higher socioeconomic level and more cultural diversity than other regions of the country.

Private motor vehicles are the most common means of transportation in the city, with 3.698.121 cars, 168.316 pick-ups and 395.649 motorcycles, totalizing 4.887.623 vehicles (14) (data from June, 2006). A large number of vehicles are involved in accidents in São Paulo urban area, including automobiles, motorcycles and bicycles. The speed limit in the urban area is 60 to $90 \mathrm{~km} / \mathrm{h}$. The use of helmets by motorcyclists and seat belt by car drivers is compulsory, and being charged with drunk driving carries risks of heavy fines.

\begin{tabular}{|lcccccccc|}
\hline Etiology & Condyle & Coronoid & Ramus & Body & Angle & Symphysis & Alveolus & Total \\
\hline Aggression & 1 & 0 & 3 & 7 & 6 & 3 & 2 & $22(14.8 \%)$ \\
Car accident & 2 & 0 & 1 & 2 & 3 & 6 & 1 & $15(10 \%)$ \\
Running over & 0 & 0 & 0 & 5 & 1 & 9 & 1 & $16(10.8 \%)$ \\
Fall & 0 & 0 & 1 & 2 & 0 & 4 & 0 & $7(4.7 \%)$ \\
Height fall & 7 & 1 & 0 & 2 & 1 & 4 & 0 & $15(10 \%)$ \\
Sport accident & 2 & 0 & 0 & 1 & 1 & 0 & 1 & $5(3.4 \%)$ \\
Gunshot wound & 0 & 0 & 1 & 10 & 2 & 0 & 1 & $14(9.4 \%)$ \\
Motorcycle accident & 4 & 2 & 0 & 13 & 2 & 10 & 3 & $34(22.8 \%)$ \\
Bicycle accident & 6 & 0 & 0 & 0 & 1 & 3 & 2 & $12(8.1 \%)$ \\
Others & 2 & 0 & 0 & 4 & 1 & 2 & 0 & $9(6.0 \%)$ \\
Total & $24(16.1 \%)$ & $3(2.0 \%)$ & $6(4 \%)$ & $46(30.9 \%)$ & $18(12.1 \%)$ & $41(27.5)$ & $11(7.4 \%)$ & $149(100 \%)$ \\
\hline
\end{tabular}

Figure 7. Interaction between the most affected anatomical fracture sites and trauma etiology.

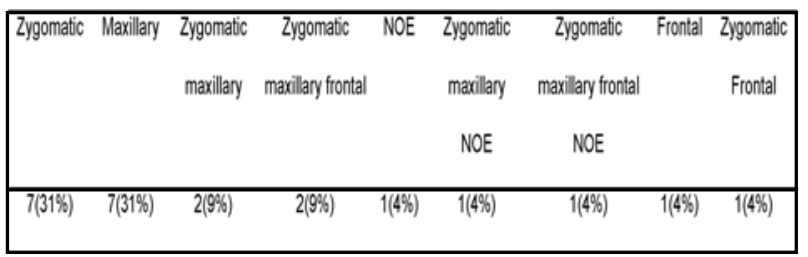

Figure 8. Number of facial fractures associated with mandible fractures (total of patients $=23$ ). NOE= naso-orbital-ethmoid.
Motorcycle accidents are associated with a larger number of facial fractures. In this survey, out of 20 victims of motorcycle accidents, $50 \%$ had other facial fractures. Other studies have reported 38.5\% (4) and $24.3 \%$ (15) of cases of motorcyclists involved in accidents with facial trauma. Car accidents were responsible for $17.39 \%$ of the associated lesions, which is close to previously reported percentages (4). Males were predominantly affected, which is in agreement with other studies $(2,4-6,11)$. Although the population has a female predominance, the number of male drivers and motorcyclists is significantly higher.

In our hospital, motorcycle accident was the main reason for mandible fractures in men aged 21 to 30 years. Perhaps, the lack of experience in traffic, imprudent driving and the type of service for which the motorcycle is generally used (fast delivery) might explain the higher incidence in young drivers. According to a survey by the Brazilian Institute of Economical Research in the year 2005 (16), 7\% of car accidents had victims, while for motorcycle accidents this value was $71 \%$. Considering the number of vehicles and the accidents with motorcycles, it is noted that the mean value of mandibular fractures in motorcycle accident victims is lower than for car accidents (1.9:1.8). However, the likelihood of mandibular fractures in motorcyclists is higher.

High speed, imprudence, use of open helmets or no use of helmets can explain the high number of fractures secondary to motorcycle accidents. Olson et al. (2) reported that wearing helmets decreases the mortality but does not reduce significantly the number of fractures and point to speed as a determinant factor

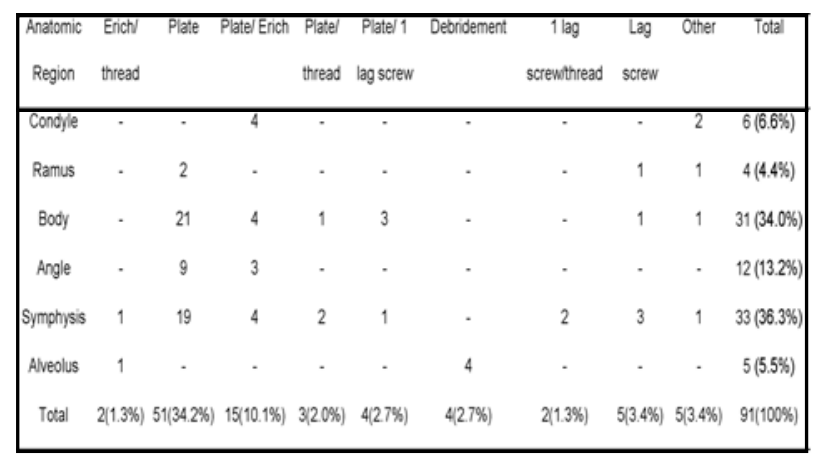

Figure 9. Distribution of the surgical treatment modalities to which the patients were submitted. 
for fracture occurrence. Other studies have reported an association between wearing a helmet and the decrease of maxillofacial lesions and the severity of skull injuries (17). A previous study (18) showed that facial trauma incidence was lower when the victims wore helmets, especially if closed. Although the Traffic National Code imposes the compulsory use of helmets and seat belt and apply severe penalties for high speed and/or drunk driving, there are still people that do not follow the law.

In this study, physical aggressions prevailed in men aged 21 to 30 years. Perhaps, robbery, excessive drinking and the high index of violence in São Paulo can explain the number of aggression-related mandibular fractures. There were no female aggression reports. However, there was a large number of height falls among young people aged between 11 and 20 years. It has been suggested that fractures due to aggressions could have been reported as falls, trying to avoid court problems $(4,6)$.

The monthly distribution of fractures was constant with a male predominance during the 12-month period. Because of the subtropical climate of the Southeast area, there were no season interferences in fracture distribution during the year.

In $25 \%$ of the patients, there were facial fractures other than mandibular fractures. These percentage is similar to that a pervious study (2) but higher than that of another (4). Ellis et al. (4) found fractures by motorcycle accident mostly in the condyle and body of the mandible while Olson et al. (2) reported condyle and angle. In the present study, mandibular body (36.1\%), symphysis $(27.7 \%)$ and condyle $(11.1 \%)$ were the most affected sites. A possible explanation for these results was the use of open helmets, which is common in São Paulo. Aggressions caused injuries mainly in the mandibular body (31.8\%) and angle (27.3\%). These findings are similar to those of Ellis et. al. (4) but are different from those of Olson et al., who reported fractures especially in the condyle and angle. In case of automobile accidents fractures have been reported to occur in the condyle and mandible body (4) or in the condyle and symphysis (2). In this survey, the most prevalent sites were symphysis and angle.

Means of mandibular fracture per patient according to the etiology were as follows: car accidents 1.9; motorcycle accidents - 1.8; falls - 1.75; physical aggression - 1.5; and height falls - 1.4. Patients who were victims of vehicle accidents had more fractures than those who suffered aggressions, which agrees with Ellis et al. (4). Considering all cases of mandibular fractures, the total mean per patient was 1.63.

Surgical treatment was done in $49.9 \%$ of the patients with 1-part fractures and $71.3 \%$ of those with 2-part fractures, which are higher rates than those reported by Ellis et al. (4). Three-part fractures were surgically reduced in 7 cases (77.8\%) as well as the only 4-part fracture. Car accidents related to the highest index of surgical reduction, while most fractures treated by closed reduction had been caused by aggression (4). Complications occurred in $19.8 \%$ of the patients. Other studies reported complications in 13\% and 21.5\% of the cases $(5,19)$. Infection ranged in several studies. Bochlogyros et al. (5) and Gabrielli et al. (11) reported infection in $7 \%$ and $10.99 \%$ of the cases, respectively. In our Service, infections were found in $13.18 \%$ of the patients and $8 \%$ of the fractures. A previous study (19) showed that there was no relation among complications by age, previous systemic diseases or treatment delay. However, differences were observed regarding the anatomical fracture site (mainly angles) and presence of tooth in the fracture line. Another work also highlighted the importance of the condition of the tooth present in the fracture line, stability and degree of fracture comminution as risk factors for infections (20). Like the results of other studies $(11,19)$, our study found $41.7 \%$ of infections in the mandible angle, $33.3 \%$ in mandible body and $25 \%$ in the symphysis. The larger number of complications caused by physical aggression maybe be due to the fact that this is the main etiology related to the angle fracture.

The number of motorcycle accidents victims in São Paulo is consistent with the fast increase in the number of motorcycles in Brazil, especially due to the trend of using them delivery services, particularly in big cities. Traffic accidents have a special relevance and a negative impact not only for their costs, but also for the pain, suffering and loss of life quality that are inflicted to the victims, their relatives and society as a whole. Perhaps specific measures are needed with respect to training of motorcyclists, definition of requirements for delivery services, improvement in education campaigns and inspection of proper helmet use.

In conclusion, motorcycle accidents were associated with a larger number of facial fractures and predominated in male aged 21 to 30 years. Fractures due to motorcycle accidents occured especially in body and 
symphysis and aggressions caused injuries mainly in the mandible body and angle. Vehicle accident victims had on average more fractures than those who suffered aggressions. Vehicle accidents were related to the highest index of surgical reduction, while most fractures treated with closed reduction were due to physical assaults. There was a correlation between angle fractures and complications. Complications related with longer hospitalization periods. Polytraumatized patients presented greater morbidity for the complications.

\section{RESUMO}

O artigo tem como objetivo revisar casos de fraturas de mandíbula atendidos no Serviço de Cirurgia Bucomaxilofacial do Conjunto Hospitalar do Mandaqui (SUS/SP), hospital de referência para trauma na região norte de cidade de São Paulo. De janeiro a dezembro de 2001, foram atendidos 98 pacientes com fraturas de mandíbula no hospital. Dentre estes, 91 casos que dispunham de dados suficientes em prontuários foram analisados. Para o estudo foram considerados: idade, gênero, etiologia, local anatômico da fratura, modalidade de tratamento, relação com fraturas de outros ossos faciais, tempo de hospitalização e complicações. Acidente motociclístico foi a principal causa de fraturas mandibulares, seguido de agressão e queda de altura. Os três locais anatômicos de maior incidência foram: corpo, sínfise e côndilo. O modo de tratamento consistiu de abordagem conservadora ou redução aberta e fixação interna. Conclui-se que acidentes motociclísticos estão associados a um maior número de fraturas mandibulares com predominância em homens de 21 a 30 anos. Vítimas de acidentes com veículos apresentaram, em média, mais fraturas do que vítimas de agressões. As complicações mostraram-se associadas ao maior período de hospitalização e fraturas de ângulo mandibular, e tiveram maior incidência em pacientes politraumatizados.

\section{ACKNOWLEDGEMENTS}

The authors wish to thank Dr. Higor Landgraf and Dr. Felipe Ladeira Pereira for their help with data collection and Mr. Luiz Martini Júnior for technical support.

\section{REFERENCES}

1. Haug RH, Savage JD, Likavec M, Conforti PJ. A review of 100 closed head injuries associated with facial fractures. J Oral Maxillofac Surg 1992;50:218-222.

2. Olson RA, Fonseca RJ, Zeitler DL, Osbon DB. Fractures of the mandible: a review of 580 cases. J Oral Maxillofac Surg 1982:40:23-28.

3. Ogundare BO, Bonnick A, Bayley N. Pattern of mandibular fractures in an urban major trauma center. J Oral Maxillofac Surg 2003:61:713-718.

4. Ellis III E, Moos KF, El-Attar A. Ten years of mandibular fractures: An analysis of 2137 cases. Oral Surg Oral Med Oral Pathol 1985;59:120-129.

5. Bochlogyros P. A retrospective study of 1521 mandibular fractures. J Oral Maxillofac Surg 1985;43:597-599.

6. Eriksson L, Willmar K. Jaw fractures in Malmö 1952-62 and 1975-85. Swed Dent J 1987;11:31-36.

7. Souza LCM, Fischman R, Silveira ME, Júnior JV. Study of 450 cases of facial bone fracture. Rev Assoc Paul Cirurg Dent 1983;37:256-260.

8. Crivello O Jr, Luz JGC, Lemos JBD, Rezende JRV. Considérations statistiques sur les fractures isolées maxillofaciales à Sao Paulo (in French). Rev Stomatol Chir Maxillofac 1989;90:100-103.

9. Klenk G, Kovacs A. Etiology and patterns of facial fractures in the United Arab Emirates. J Craniofac Surg 2003;14:7874 .

10. Valente ROH, Souza LCM, Antonini SV, Glock L, NisaCastro-Neto W. Epidemiology of mandibular fractures assisted at Santa Casa de Misericórdia de São Paulo Hospital (HSCSP) between 1996 and 1998. Revista Bras Cir Period 2003;1:141-146.

11. Gabrielli MAC, Gabrielli MFR, Marcantonio E, Hochuli-Vieira E. Fixation of mandibular fractures with $2.0 \mathrm{~mm}$ miniplates: Review of 191 cases. J Oral Maxillofac Surg 2003;61:430436.

12. Banks P. Killey's fractures of the mandible. 4th ed. London: Wright, 1991.

13. Brazilian Institute of Geography and Statistics (IBGE). Preliminary projection of the Brazilian population - Revision 2000. Ministry of National Planning and Administration. Brazilian Federal Government. 2000. Available from www.ibge.gov.br (Latest Access August 26, 2006).

14. Nacional Traffic Department (DenaTran) 2006. Brazilian Federal Government. Available from www.denatran.gov.br. (Latest Access August 27, 2006).

15. Dickenson AJ, Yates JM. Helmet use and maxillofacial injuries sustained following low speed motorcycle accidents. Int $\mathrm{J}$ Care Injured 2002;33:479-483.

16. Brazilian Institute of Economical Research (IPEA). Ministry of National Planning and Administration. Brazilian Federal Government. 2005. Available from www.ipea.gov.br. (Latest Access August 27, 2006).

17. Johnson RM, McCarthy MC, Miller SF, Peoples JB. Craniofacial trauma in injured motorcyclists: the impact of helmet usage. J Trauma 1995;38:876-878.

18. Vaughan RG. Motorcycle helmets and facial injuries. Med J Aust 1977:1:125-127.

19. Wagner WF, Neal DC, Alpert B. Morbidity associated with extraoral open reduction of mandibular fractures. J Oral Surg 1979;37:97-100.

20. Topazian RG, Golberg MH. Oral and Maxillofacial Infections. 3rd ed. Philadelphia: WB Saunders, 1997.

Accepted September 6, 2005 